\title{
Comparison of the effectiveness of radiotherapy with photons, protons and carbon-ions for non-small cell lung cancer: A meta-analysis
}

Citation for published version (APA):

Grutters, J. P. C., Kessels, A. G. H., Pijls-Johannesma, M., De Ruysscher, D., Joore, M. A., \& Lambin, P. (2010). Comparison of the effectiveness of radiotherapy with photons, protons and carbon-ions for nonsmall cell lung cancer: A meta-analysis. Radiotherapy and Oncology, 95(1), 32-40. https://doi.org/10.1016/j.radonc.2009.08.003

Document status and date:

Published: 01/04/2010

DOI:

10.1016/j.radonc.2009.08.003

Document Version:

Publisher's PDF, also known as Version of record

Document license:

Taverne

Please check the document version of this publication:

- A submitted manuscript is the version of the article upon submission and before peer-review. There can be important differences between the submitted version and the official published version of record.

People interested in the research are advised to contact the author for the final version of the publication, or visit the DOI to the publisher's website.

- The final author version and the galley proof are versions of the publication after peer review.

- The final published version features the final layout of the paper including the volume, issue and page numbers.

Link to publication

\footnotetext{
General rights rights.

- You may freely distribute the URL identifying the publication in the public portal. please follow below link for the End User Agreement:

www.umlib.nl/taverne-license

Take down policy

If you believe that this document breaches copyright please contact us at:

repository@maastrichtuniversity.nl

providing details and we will investigate your claim.
}

Copyright and moral rights for the publications made accessible in the public portal are retained by the authors and/or other copyright owners and it is a condition of accessing publications that users recognise and abide by the legal requirements associated with these

- Users may download and print one copy of any publication from the public portal for the purpose of private study or research.

- You may not further distribute the material or use it for any profit-making activity or commercial gain

If the publication is distributed under the terms of Article $25 \mathrm{fa}$ of the Dutch Copyright Act, indicated by the "Taverne" license above, 
Meta-analysis

\title{
Comparison of the effectiveness of radiotherapy with photons, protons and carbon-ions for non-small cell lung cancer: A meta-analysis
}

\author{
Janneke P.C. Grutters ${ }^{\mathrm{a}, *}$, Alfons G.H. Kessels ${ }^{\mathrm{b}}$, Madelon Pijls-Johannesma ${ }^{\mathrm{a}}$, Dirk De Ruysscher ${ }^{\mathrm{a}}$, \\ Manuela A. Joore ${ }^{\mathrm{b}, 1}$, Philippe Lambin ${ }^{\mathrm{a}, 1}$ \\ a Department of Radiation Oncology (MAASTRO Clinic), Maastricht University Medical Centre, The Netherlands \\ ${ }^{\mathrm{b}}$ Department of Clinical Epidemiology and Medical Technology Assessment, Maastricht University Medical Centre, The Netherlands
}

\section{A R T I C L E I N F O}

\section{Article history:}

Received 18 March 2009

Received in revised form 8 July 2009

Accepted 1 August 2009

Available online 3 September 2009

\section{Keywords:}

Meta-analysis

Particle therapy

Evidence synthesis

Proton

Photon

Carbon-ion

\begin{abstract}
A B S T R A C T
Purpose: To provide a comparison between radiotherapy with photons, protons and carbon-ions in the treatment of Non-Small-Cell Lung Cancer (NSCLC), performing a meta-analysis of observational studies. Methods: Eligible studies on conventional radiotherapy (CRT), stereotactic radiotherapy (SBRT), concurrent chemoradiation (CCR), proton therapy and carbon-ion therapy were searched through a systematic review. To obtain pooled estimates of 2- and 5-year disease-specific and overall survival and the occurrence of severe adverse events for each treatment modality, a random effects meta-analysis was carried out. Pooled estimates were corrected for effect modifiers. Results: Corrected pooled estimates for 2-year overall survival in stage I inoperable NSCLC ranged from $53 \%$ for CRT to $74 \%$ for carbon-ion therapy. Fiveyear overall survival for CRT (20\%) was statistically significantly lower than that for SBRT (42\%), proton therapy (40\%) and carbon-ion therapy (42\%). However, caution is warranted due to the limited number of patients and limited length of follow-up of the particle studies. Conclusion: Survival rates for particle therapy were higher than those for CRT, but similar to SBRT in stage I inoperable NSCLC. Particle therapy may be more beneficial in stage III NSCLC, especially in reducing adverse events.
\end{abstract}

(c) 2009 Elsevier Ireland Ltd. All rights reserved. Radiotherapy and Oncology 95 (2010) 32-40
Particle therapy (both protons and carbon-ions) has a better dose distribution compared to photons. This physical advantage of particle therapy can be used to reduce radiotherapy-induced adverse events by sparing normal tissue using similar dosage or to improve tumor control by giving a higher dose to the tumor but a similar dose to the normal tissue. Because of this theoretical advantage particle therapy gained increasing attention in the last decade.

Several papers were recently published that reviewed the effectiveness of particle therapy [1-5]. The main conclusion of these reviews was that there are almost no randomized clinical trials (RCTs) comparing particle therapy with conventional photon therapy. The lack of RCTs makes it difficult to draw firm conclusions about the clinical benefit of particle therapy. This resulted in an ongoing discussion about whether or not RCTs are required before particle therapy can become the treatment of choice for different types of cancer [6-12]. While it is acknowledged that implementation of new technologies should be evidence-based, it is questioned whether it is ethical to randomize patients to a radiotherapy delivery technique that has an obvious inferior dose distribution to nor-

\footnotetext{
* Corresponding author. Address: Maastricht University, Dept. of Health Organization, Policy and Economics, P.O. Box 616, 6200 MD Maastricht, The Netherlands.

E-mail address: janneke.grutters@maastro.nl (J.P.C. Grutters).

1 These authors contributed equally to this work.
}

mal tissue. The societal impact of this controversial topic is illustrated by the fact that also patients intervened in this discussion, stressing the importance of a meticulous consideration of all possible pros and cons [13].

For non-small cell lung cancer (NSCLC) only observational studies on particle therapy are published, mostly on stage I inoperable disease [4]. Although the results seem promising in comparison with conventional radiotherapy, stereotactic body radiotherapy (SBRT) also shows good results for these patients, comparable with the results of surgery [14]. Unfortunately, the available studies are difficult to compare as the study populations are often divergent. For example, the studies report on a mix of medically inoperable patients and patients who refused surgery. Medically inoperable patients are not sufficiently fit for surgery because of their poor condition. The difference in the percentage of medically inoperable patients between study populations may thus influence the study outcome, and hamper the comparison between different treatment modalities.

Even less data are available on the effectiveness of particle therapy in advanced NSCLC. Most patients with advanced NSCLC are poor in general health and concurrent chemotherapy can only be applied in combination with small irradiation target volumes. Because of its potential of sparing normal tissue, particle therapy may be especially beneficial in advanced stage NSCLC. 
Despite the lack of randomized trials, decisions need to be made, and the single-arm studies are all the evidence that is currently available. The purpose of this paper is therefore to provide a comparison between radiotherapy with photons, protons and carbon-ions in the treatment of NSCLC, performing a meta-analysis based on published observational studies.

\section{Methods}

This meta-analysis was performed according to the guidelines proposed by the Meta-Analysis of Observational Studies in Epidemiology group [15].

\section{Search strategy and selection criteria}

A recent systematic literature review on particle therapy in lung cancer [4] was updated until August 2008 to identify the studies on the effectiveness of particle therapy. Since for CCR an extensive Cochrane review and meta-analysis on individual patient data were already performed, we decided to use the results from these studies for CCR $[16,17]$. The studies on the effectiveness of conventional radiotherapy alone (CRT), including hyperfractionated radiation schedules, and SBRT were identified through a predefined search. The following electronic databases were used: the Cochrane library, PubMed and MEDLINE, over the last 15 years (1994 to August 2008). The search included the following terms: ('lung cancer' or 'NSCLC') and ('Lung neoplasms/radiotherapy'[MESH terms] or 'Carcinoma, Non-Small-Cell Lung/radiotherapy'[MESH terms]) and 'survival'. Additional references were searched through manual searches of the reference lists and specialist journals.

The studies were included if they were written in English or Dutch, and if they reported original data and 2- or 5-year (disease-specific) survival results for one or more disease stage(s) separately. In accordance with the previous review on particle therapy [4], only the studies with more than 20 patients were included.

\section{Data extraction}

Two investigators (J.G. and M.P.J.) independently extracted relevant data from the studies. General characteristics were recorded from each study: first author, year of publication, study design, treatment type, sample size, dose per fraction, number of fractions, total dose, overall treatment time (OTT), study population (age, percentage of medically inoperable patients, percentage of patients with tumors smaller than $3 \mathrm{~cm}$ ) and follow-up period. To compare the total doses we calculated the biological equivalent dose for tumor in $2 \mathrm{~Gy}$ fractions, corrected for the overall treatment time, using the formula $E Q D_{2, T}=D *[(d+(\alpha / \beta)) /(2+(\alpha / \beta))]-\left[\left(T-T_{\text {ref }}\right) * D_{\text {prolif }}\right][18]$. In this formula $D$ represents the total radiation dose, $d$ the dose per fraction and $T$ the overall treatment time. An $\alpha / \beta$ ratio of $10 \mathrm{~Gy}$ was used for tumor tissue [18]. The value for $T_{\text {ref }}$ was chosen at 21 days ( 3 weeks). Before day 21 repopulation was assumed to be zero, while after day 21 the dose recovered per day in 2 Gy equivalent fractions ( $\left.D_{\text {prolif }}\right)$ was assumed to be $0.6 \mathrm{~Gy}$ [18].

The 2- and 5-year overall and disease-specific survival rates were extracted from each study, as well as the occurrence of grade $3 / 4$ pneumonitis, grade 3/4 oesophagitis, grade 3/4 irreversible dyspnoea and grade 5 adverse events (treatment-related death). Adverse events were graded according to the Common Terminology Criteria for Adverse Events (CTCAE), version 3.0 [19].

\section{Data analysis}

To obtain pooled estimates of the effectiveness of the different treatment modalities, a meta-analysis was used to determine weighted summary statistics for each of the treatments. If between-study variation was present, a random effect model was used to take this heterogeneity into account [20].

Since differences between the characteristics of the study populations may influence the effectiveness of different treatment modalities, we explored whether such effect modifiers were present. We did this by including each characteristic (age, percentage of tumors smaller than $3 \mathrm{~cm}$, percentage of medically inoperable patients and follow-up period) in the regression model separately. The characteristics that had a statistically significant influence on the regression model were defined as effect modifiers. We corrected for these effect modifiers in the final meta-analysis by estimating the models for the overall mean value of that characteristic. We did this by calculating for each study how much the characteristic deviated from the overall mean for all studies. This difference was incorporated as an independent variable in the meta-regression model.

Missing data on the characteristics of the studies were handled using multiple imputation. Instead of filling in a single value for each missing value, Rubin's multiple imputation procedure generates $m$ datasets, each of which replaces each missing value with a plausible value, that represent the uncertainty about the right value to impute [21]. With regression models the missing value of a specific variable is predicted using the other variables, i.e. the covariates and outcome. In the multiple imputation method the imputed variables are drawn from the density function as generated by the regression model [22]. This results in statistically valid inferences that properly reflect the uncertainty due to missing values. We created five datasets $(m=5)$.

Meta-analyses were performed to obtain pooled estimates for 2- and 5-year overall and disease-specific survival, as well as the occurrence of adverse events for each treatment modality. The data were managed in SPSS 15.0 and analyzed using STATA 9.

\section{Results}

\section{Selected articles and characteristics}

Regarding the search on CRT and SBRT, on the basis of the keywords, 1711 articles were found. Excluding papers with review as publication type left 1289 , of which another 1102 were excluded based on the screening of the titles. Most excluded references were papers on chemoradiation, advanced stage NSCLC or planning studies. Of the remaining 187 references the abstracts were screened and, if necessary, the papers were retrieved and the data were analyzed. Of these 187 references another 159 were excluded based on the exclusion criteria. One additional reference on SBRT was retrieved through manual searches of the reference lists [23]. As two SBRT papers reported on patients in a Japanese multi-institutional study $[24,25]$, only the most recent paper was included [25]. An earlier version of the paper as well as other studies from participating institutions was excluded, to prevent duplication [24,26-30]. Two other studies reported on the same patient population [23,31]. We chose to include the study by Hoyer et al. [23] as this was a prospective study with a stronger focus on survival and all patients received the same fractionation schedule, as opposed to the divergent fractionation schedules analyzed retrospectively by Baumann et al. [31]. Ultimately, 22 studies that met the inclusion criteria were identified: 11 studies on CRT [3242] and 11 studies on SBRT [23,25,43-51].

The particle therapy review resulted in five studies on proton therapy [52-56] and three studies on carbon-ion therapy [5759]. No additional references were found since the previous search [4]. The search on both particle therapy and photon therapy is illustrated in a flow diagram in Appendix 1.

All studies on particle therapy, CRT and SBRT reported results for stage I NSCLC separately. The results for stage II NSCLC were 
only reported by two SBRT studies ( $n=27$ ) [47,51]. The results for stage III NSCLC were reported by two proton studies, each reporting on only 8 patients $[52,56]$. Due to the lack of the data for particle therapy on advanced stage NSCLC we decided not to include these patient groups in the meta-analysis.

The study characteristics for the included studies are tabulated in Table 1. We included both retrospective and prospective studies. One non-randomized study was found on proton therapy. In this study by Bush et al. the patients were assigned to the treatment arms based on cardiopulmonary function and the results were presented for the total group only [52]. All other included studies were single-arm studies.

The percentage of tumors smaller than $3 \mathrm{~cm}$ was very diverse, ranging from $19 \%$ to $100 \%$ in the studies on stage I disease. The percentage of medically inoperable patients ranged from $42 \%$ to $100 \%$. The $E Q D_{2, T}$ ranged from 32 to $176 \mathrm{~Gy}$ between the studies, and also ranged within the studies.

\section{Exploration of influencing baseline characteristics}

Entering age, percentage of small tumors $(<3 \mathrm{~cm})$ and median follow-up in the random effect meta-regression model did not influence the treatment coefficients and increased the variance of these coefficients. This indicates that these characteristics were not modifying the results and should not be corrected for. Only the percentage of medically inoperable patients was found to statistically significantly influence the coefficients and reduce the variance of the coefficients in the model. We therefore corrected the outcomes in the meta-analysis for differences in the percentage of medically inoperable patients only. This means that the corrected pooled estimates apply to a study population with $82 \%$ medically inoperable patients, which was the mean for all studies.

\section{Survival for stage I NSCLC after two years}

All but one [53] study reported 2-year overall survival (Fig. 1). The results of the random effect meta-analysis on 2-year overall survival are presented in Table 2 . The corrected 2-year overall survival estimates and their 95\% confidence intervals were 53\% (46$60 \%$ ) for CRT, $70 \%(63-77 \%)$ for SBRT, $61 \%$ (47-75\%) for proton therapy and $74 \%$ (61-86\%) for carbon-ion therapy. The uncorrected 2-year survival estimates were slightly lower than the corrected estimates for CRT and SBRT, while the uncorrected estimates were higher than the corrected estimates for protons and carbon-ions (Fig. 1). The corrected pooled 2-year overall survival for CRT was statistically significantly lower than that for SBRT ( $p$-value $<0.001$ ) and carbon-ion therapy ( $p$-value 0.006 ). SBRT, proton therapy and carbon-ion therapy did not have statistically significantly different 2-year overall survival rates.

Six CRT studies [33,35,37-39,41], six SBRT studies $[23,43,45,46,48,51]$, three proton studies [53,54,56], and three carbon-ion studies [57-59] reported 2-year disease-specific survival. The corrected 2-year disease-specific survival estimates and their $95 \%$ confidence intervals were $67 \%(59-76 \%)$ for CRT, $83 \%$ (75-92\%) for SBRT, $74 \%$ (61-87\%) for proton therapy and $82 \%$ (70-93\%) for carbon-ion therapy (Table 2). The pooled 2-year disease-specific survival rate for CRT was statistically significantly lower than that for SBRT ( $p$-value 0.006). The differences in 2-year disease-specific survival between SBRT, proton therapy and carbon-ion therapy were not statistically significant.

\section{Survival for stage I NSCLC after five years}

Ten studies on CRT [32-38,40-42], five studies on SBRT $[25,43,45,46,51]$, two studies on proton therapy $[55,56]$ and all three studies on carbon-ion therapy [57-59] reported 5-year overall sur- vival (Fig. 2). Because of the limited follow-up in both the SBRT and particle studies, 5-year outcomes should be interpreted with caution.

The corrected pooled estimates for 5-year overall survival and their 95\% confidence intervals were 19\% (15-24\%) for CRT, $42 \%$ (34-50\%) for SBRT, $40 \%$ (24-55\%) for proton therapy and $42 \%$ (32-52\%) for carbon-ion therapy (Table 3). Correcting for the percentage of medically inoperable patients in a study population increased the survival rate of CRT, but lowered the pooled estimates of SBRT, proton therapy and carbon-ion therapy (Fig. 2). The corrected pooled 5-year overall survival for CRT was statistically significantly lower than that for SBRT ( $p$-value $<0.001$ ), proton therapy ( $p$-value 0.014 ) and carbon-ion therapy ( $p$-value $<0.001$ ). SBRT, proton therapy and carbon-ion therapy did not have statistically significantly different 5 -year overall survival.

Five CRT studies [33,35,37,38,41], five SBRT studies $[25,43,45,46,51]$, two proton studies [53,56], and three carbonion studies [57-59] reported 5-year disease-specific survival. The corrected pooled estimates for 5-year disease-specific survival ranged from $43 \%$ for CRT to $64 \%$ after carbon-ion therapy (Table 3 ). Five-year disease-specific survival for CRT (43\%) was statistically significantly lower than that for SBRT (63\%; $p$-value 0.045 ).

\section{Occurrence of adverse events}

In stage I NSCLC the occurrence of severe adverse events (CTCAE grade 3-5 [19]) was infrequent for all treatment modalities. The majority of studies reported zero adverse events. Combining studies with zero events is problematic because continuity corrections are needed, which can influence the results [60]. To avoid the use of continuity corrections we decided to add up the adverse events occurring for each treatment modality, instead of pooling the estimates using a meta-regression. The total occurrence of each adverse event per treatment modality, as well as the number of patients at risk, is listed in Table 4. Proportions and 95\% confidence intervals were calculated using a binomial distribution. The number of patients at risk varies because not all studies reported all adverse events. In Table 4 we therefore also reported which studies were used to derive each figure.

Overall, the SBRT studies reported somewhat more adverse events than the CRT studies, mainly regarding pneumonitis and treatment-related death. However, the six treatment-related deaths after SBRT were all from a single study with a high biological equivalent dose and including peripherally located tumors [50]. This study also reported eight cases of grade 3/4 adverse events, but because they did not specify the types of adverse events, these were not incorporated in the count. The SBRT studies also reported more adverse events than the proton and carbon-ion studies, which is only partly attributable to the lower number of patients at risk in the particle therapy studies. Particle therapy resulted in no grade 3/4 oesophagitis, dyspnoea or treatment-related deaths, while only 4 out of 336 patients with stage I NSCLC treated with particle therapy had grade $3 / 4$ pneumonitis.

\section{Discussion}

To the best of our knowledge, this meta-analysis was the first to pool the effectiveness of CRT, SBRT, proton therapy and carbon-ion therapy in the treatment of stage I NSCLC, to allow for a comparison between particle therapy and photon therapy. A total of 30 studies met the inclusion criteria and were used in the meta-analysis. Two- and five-year (disease-specific) survival rates, corrected for differences in the percentage of medically inoperable patients in the studies, were lower for CRT than for the other treatment modalities. The corrected survival rates for SBRT, proton therapy and carbon-ion therapy were comparable. Because of the limited follow-up in both the SBRT and particle studies, 5-year outcomes 
Table 1

Study and population characteristics for studies on stage I NSCLC.

\begin{tabular}{|c|c|c|c|c|c|c|c|c|c|c|c|c|c|}
\hline First author & Year & $\begin{array}{l}\text { Study } \\
\text { design }\end{array}$ & $\begin{array}{l}\text { Treatment } \\
\text { type }\end{array}$ & $\begin{array}{l}\text { Sample } \\
\text { size }\end{array}$ & $\begin{array}{l}\text { Fraction } \\
\text { dose (Gy) }\end{array}$ & $\begin{array}{l}\text { Fraction } \\
\text { number }\end{array}$ & $\begin{array}{l}\text { Total dose } \\
\text { (Gy) }\end{array}$ & OTT (weeks) & $E Q D_{2, \mathrm{~T}}$ & $\begin{array}{l}\text { Median/mean } \\
\text { age (range) }\end{array}$ & $\%$ tumors $<3 \mathrm{~cm}$ & $\begin{array}{l}\text { \% Medically } \\
\text { inoperable }\end{array}$ & $\begin{array}{l}\text { Median FU in } \\
\text { months (range) }\end{array}$ \\
\hline Gauden [30] & 1995 & $\mathrm{R}$ & CRT & 347 & 2.5 & 20 & 50 & 4 & 48 & $70(34-90)$ & 48 & 64 & 22 \\
\hline Krol [36] & 1996 & $\mathrm{R}$ & CRT & 108 & $2.5-3$ & $20-26$ & $60-65$ & $5-7$ & $51-57$ & $74(56-88)$ & 47 & 94 & NR \\
\hline Jeremic [40] & 1997 & $\mathrm{P}$ & CRT & 49 & 1.2 & 58 & 70 & 6 & 54 & $63(51-70)$ & 51 & 59 & NR \\
\hline Morita [32] & 1997 & $\mathrm{R}$ & CRT & 149 & 2 & $27-38$ & $55-74$ & $5-8$ & $46-57$ & $74(50-89)$ & 40 & 83 & 91 \\
\hline Sibley [33] & 1998 & $\mathrm{R}$ & CRT & 141 & $1.8-3$ & NR & $50-80$ & $4-10$ & NC & $70(46-95)$ & 54 & 99 & $24(7-132)$ \\
\hline Hayakawa [35] & 1999 & $\mathrm{R}$ & CRT & 36 & 2 & $30-40$ & $60-81$ & $6-8$ & $47-59$ & $\mathrm{NR}$ & 19 & 89 & $\mathrm{NR}$ \\
\hline Firat [34] & 2002 & $\mathrm{R}$ & CRT & 50 & NR & NR & $31-77$ & $\mathrm{NR}$ & NC & $69(52-83)$ & 50 & NR & NR \\
\hline Lagerwaard [31] & 2002 & $\mathrm{R}$ & CRT & 113 & $2-2.5$ & $28-35$ & $60-72$ & $5-7$ & $47-60$ & $74(49-87)$ & 58 & 90 & 29 \\
\hline Bradley [37] & 2003 & $\mathrm{P}$ & CRT & 56 & $1.8-2$ & $30-42$ & $60-84$ & $6-8$ & $42-63$ & $73(52-90)$ & 55 & 100 & $20(15-72)$ \\
\hline Fang [39] & 2006 & $\mathrm{R}$ & CRT & 85 & NR & NR & $45-90$ & NR & NC & 73 & 64 & 82 & $19(2-77)$ \\
\hline Din [38] & 2008 & $\mathrm{P} / \mathrm{R}$ & CRT & 192 & 1.5 & 36 & 54 & 2 & 57 & $71^{*}$ & 39 & NR & Minimum 24 \\
\hline Uematsu [44] & 2001 & $\mathrm{R}$ & SBRT & 50 & $5-12$ & $5-10$ & $50-60$ & $1-2$ & $63-110$ & $71(54-86)$ & 48 & 42 & 36 \\
\hline Hoyer [21] & 2006 & II & SBRT & 40 & 15 & 3 & 45 & 1 & 94 & $70(46-80)$ & 55 & 100 & $29(13-58)$ \\
\hline Nyman [43] & 2006 & $\mathrm{P}$ & SBRT & 45 & 15 & 3 & 45 & 1 & 94 & $74(58-84)$ & 40 & 100 & $43(24-74)$ \\
\hline Timmerman [48] & 2006 & II & SBRT & 70 & $20-22$ & 3 & $60-66$ & $1-2$ & $150-176$ & $70(51-86)$ & 50 & 100 & $18(1-44)$ \\
\hline Zimmermann [46] & 2006 & $\mathrm{I} / \mathrm{II}$ & SBRT & 68 & $6-12.5$ & $3-5$ & $24-40$ & NR & $32-50$ & $76(59-92)$ & 100 & 100 & $17(3-44)$ \\
\hline Xia [45] & 2006 & $\mathrm{P}$ & SBRT & 25 & 7 & 10 & 70 & 2 & 99 & $71(44-88)^{*}$ & 42 & 100 & $27(24-54)$ \\
\hline Koto [41] & 2007 & II & SBRT & 31 & $7.5-15$ & $3-8$ & $45-60$ & $1-2$ & $88-94$ & $77(60-83)$ & 61 & 65 & $32(4-87)$ \\
\hline Onishi [23] & 2007 & $\mathrm{R}$ & SBRT & 257 & $4.4-35$ & $1-14$ & $30-84$ & NR & $\mathrm{NC}$ & $74(39-92)$ & 64 & 61 & $38(2-128)$ \\
\hline Scorsetti [47] & 2007 & $\mathrm{P}$ & SBRT & 43 & $7-10$ & $2-4$ & $20-32$ & NR & $33-40$ & $74(52-90)$ & 67 & 100 & $14(6-36)$ \\
\hline Lagerwaard [42] & 2008 & $\mathrm{P}$ & SBRT & 206 & $7.5-20$ & $3-8$ & 60 & NR & $90-150$ & 73 & 59 & 81 & $12(3-44)$ \\
\hline Salazar [49] & 2008 & $\mathrm{P}$ & SBRT & 60 & 13 & 4 & 52 & 3 & 100 & $75(53-93)^{*}$ & 75 & 100 & $38(2-84)$ \\
\hline Bush [50] & 1999 & $P$ & Proton & 26 & $1.8-5.1$ & $10-41$ & $51-74$ & $2-5$ & 64 & $72(54-87)^{*}$ & 44 & NR & $14(3-44)$ \\
\hline Shioyama [54] & 2003 & $\mathrm{R}$ & Proton & 28 & $2-6$ & $7-32$ & $49-93$ & $1.5-11$ & NC & $74(25-87)^{*}$ & 32 & NR & $30(18-153)$ \\
\hline Bush [51] & 2004 & II & Proton & 68 & $5.1-6$ & 10 & $51-60$ & 2 & $64-80$ & $72(52-87)$ & 43 & 93 & NR \\
\hline Nihei [53] & 2006 & $\mathrm{R}$ & Proton & 37 & $3.5-4.7$ & 20 & $70-94$ & $4-5$ & $70-111$ & $75(63-87)$ & 46 & 62 & $24(3-62)$ \\
\hline Hata [52] & 2007 & $\mathrm{P}$ & Proton & 21 & $5-6$ & 10 & $50-60$ & 2 & $63-80$ & $74(51-85)$ & 52 & 43 & $25(10-54)$ \\
\hline Miyamoto [57] & 2003 & $\mathrm{I} / \mathrm{II}$ & Carbon-ion & 81 & $3.3-8.8$ & $9-18$ & 59-95 & $3-6$ & $53-124$ & $72(47-85)$ & 50 & 74 & 53 \\
\hline Miyamoto [56] & 2007 & II & Carbon-ion & 50 & 8 & 9 & 72 & 3 & 108 & $74(61-84)$ & 59 & 66 & $59(6-83)$ \\
\hline Miyamoto [55] & 2007 & I/II & Carbon-ion & 79 & $13.2-15$ & 4 & $53-60$ & 1 & $102-125$ & $75(47-88)$ & 53 & 78 & $39(3-72)$ \\
\hline
\end{tabular}

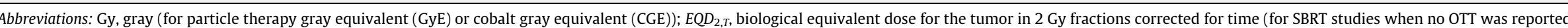

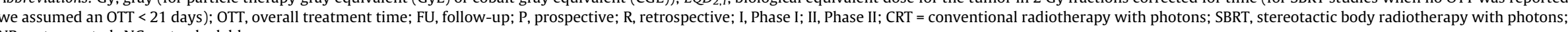
NR, not reported; NC, not calculable.

" Population characteristics are for total study population, including other disease stages. 


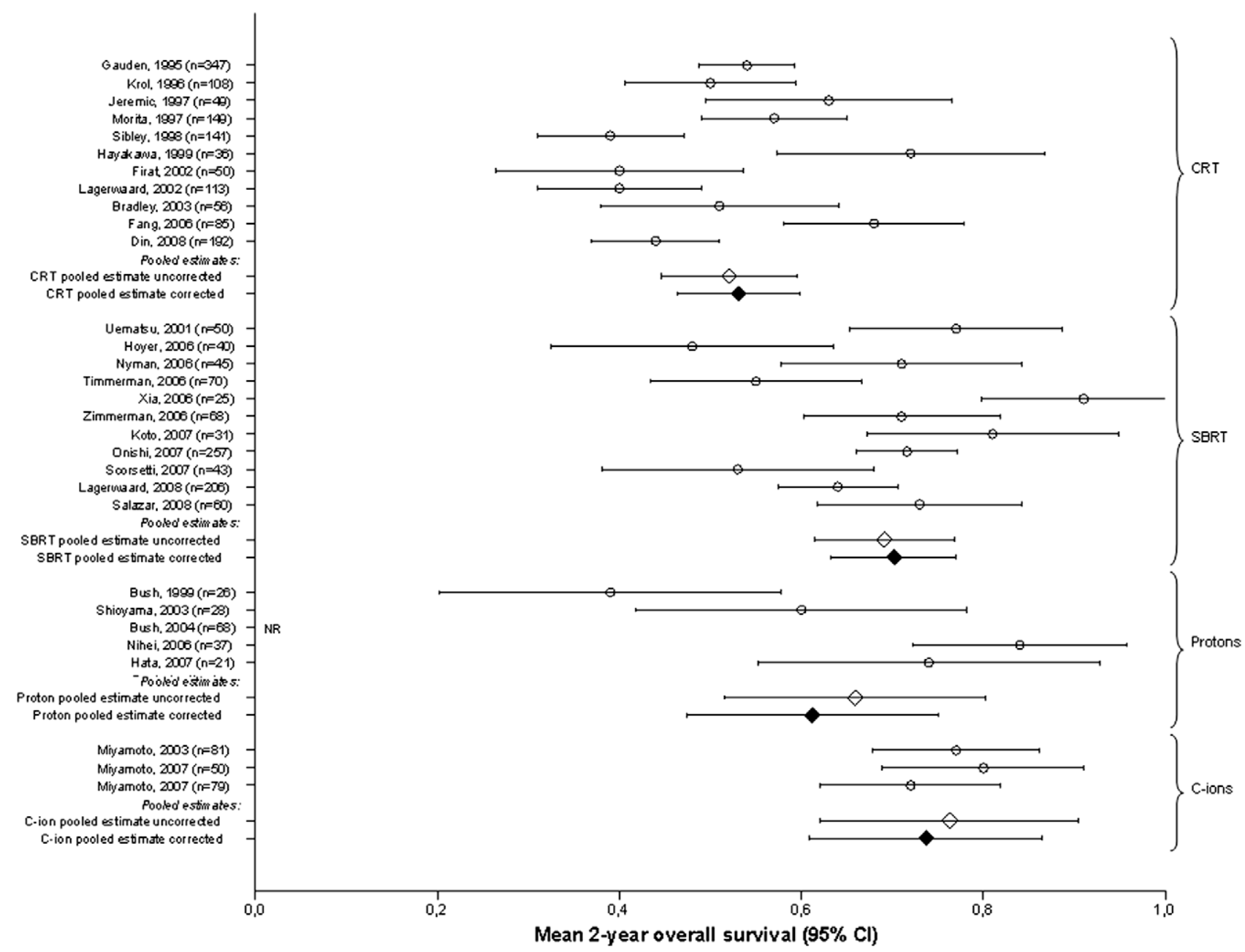

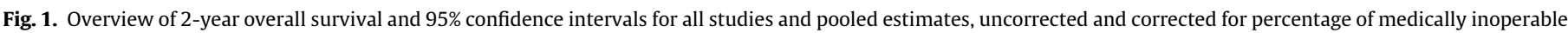
patients, per treatment modality (NR, not reported).

Table 2

Results of meta-analysis for 2-year (disease-specific) survival.

\begin{tabular}{|c|c|c|c|c|c|}
\hline \multirow[t]{2}{*}{ Treatment } & \multirow[t]{2}{*}{ 2-year overall survival } & \multirow[t]{2}{*}{$(95 \% \mathrm{CI})$} & \multicolumn{3}{|c|}{$p$-Value ${ }^{* *}$} \\
\hline & & & SBRT & Protons & Carbon-ions \\
\hline CRT & 0.531 & $(0.464-0.599)$ & $<0.001$ & 0.310 & 0.006 \\
\hline SBRT & 0.702 & $(0.633-0.770)$ & & 0.262 & 0.638 \\
\hline Protons & 0.612 & $(0.474-0.750)$ & & & 0.180 \\
\hline \multirow[t]{2}{*}{ Carbon-ions } & 0.737 & $(0.609-0.864)$ & & & \\
\hline & 2-year disease-specific survival & & & & \\
\hline CRT & 0.674 & $(0.587-0.761)$ & 0.006 & 0.430 & 0.065 \\
\hline SBRT & 0.834 & $(0.751-0.917)$ & & 0.246 & 0.797 \\
\hline Protons & 0.740 & $(0.607-0.874)$ & & & 0.391 \\
\hline Carbon-ions & 0.815 & $(0.700-0.930)$ & & & \\
\hline
\end{tabular}

Abbreviations: CI, confidence interval; CRT, conventional radiotherapy; SBRT, stereotactic body radiotherapy.

* Pooled estimates are based on a study population with $82 \%$ medically inoperable patients.

** $p$-Value for the difference between the treatments.

should however be interpreted with caution. Particle therapy and conventional radiotherapy appeared to result in less adverse events than SBRT, but adverse events were difficult to compare due to poor or incongruous reporting. Due to a lack of data no pooled estimates were derived for more advanced stages of NSCLC.

The application of formal meta-analytic methods to observational studies has been controversial [61]. One of the most important reasons for this is that the designs and populations of the studies are diverse, and that these differences may influence the pooled estimates. However, when no RCTs are available, as is the case for parti- cle therapy in lung cancer, a meta-analysis of observational studies is one of the few methods for assessing efficacy and effectiveness [15]. Moreover, it represents the uncertainty surrounding the pooled estimates, and is a valuable method to inform the decision whether more evidence is needed, which is a timely discussion topic with regard to particle therapy [6-13]. When studies are well documented, a meta-analysis also allows to correct for potentially modifying differences between study populations or designs, as has been done in the current study. However, potential bias may have occurred because the CRT studies were overall older than the SBRT and particle 


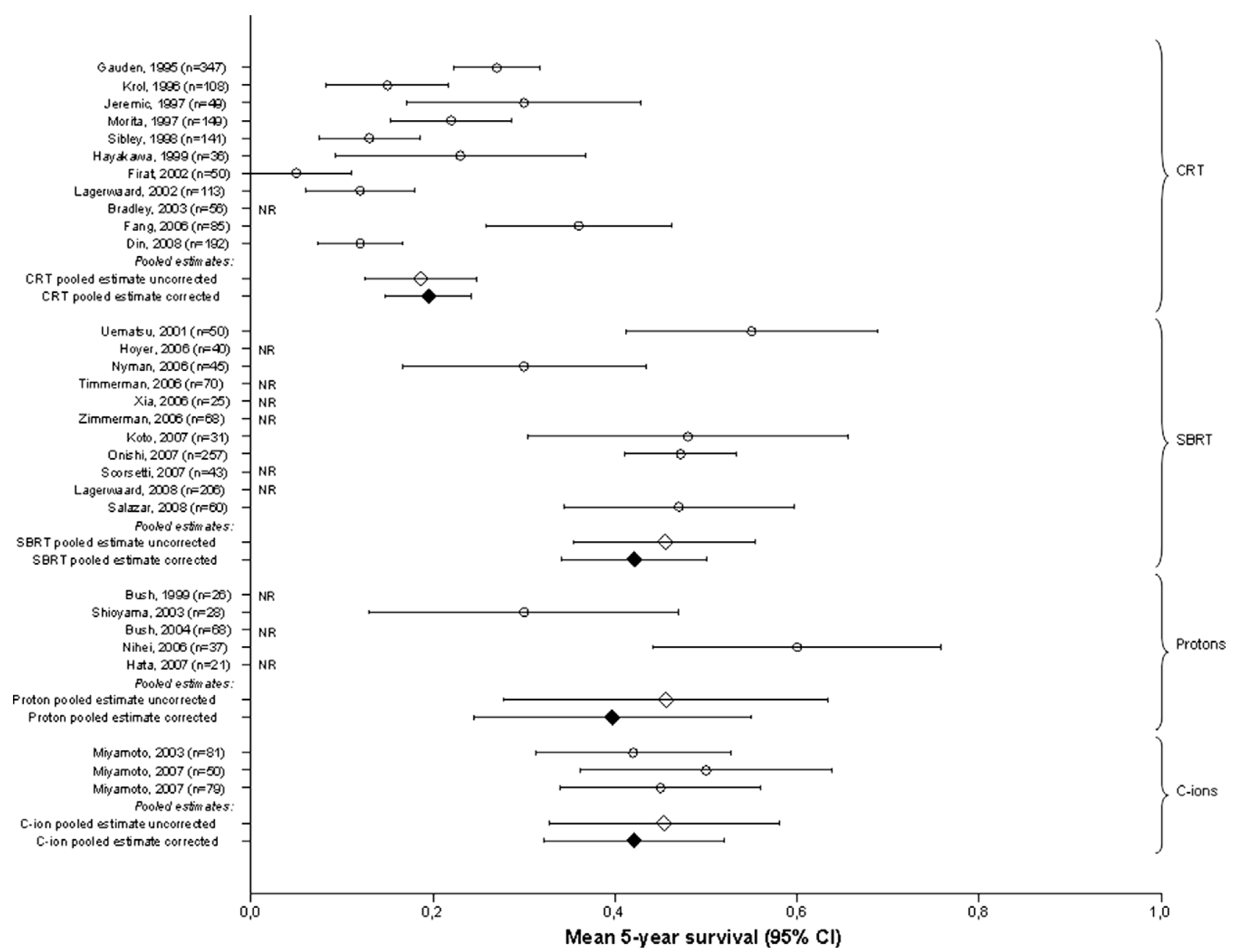

Fig. 2. Overview of 5-year overall survival and $95 \%$ confidence intervals for all studies and pooled estimates, uncorrected and corrected for percentage of medically inoperable patients, per treatment modality (NR, not reported).

Table 3

Results of meta-analysis for 5-year (disease-specific) survival."

\begin{tabular}{|c|c|c|c|c|c|}
\hline \multirow[t]{2}{*}{ Treatment } & \multirow{2}{*}{5 -year overall survival } & \multirow[t]{2}{*}{$(95 \% \mathrm{CI})$} & \multicolumn{3}{|c|}{$p$-Value ${ }^{* *}$} \\
\hline & & & $\begin{array}{l}\text { SBRT } \\
\end{array}$ & Protons & Carbon-ions \\
\hline CRT & 0.195 & $(0.148-0.242)$ & $<0.001$ & 0.014 & $<0.001$ \\
\hline SBRT & 0.421 & $(0.341-0.501)$ & & 0.782 & 0.985 \\
\hline \multirow[t]{2}{*}{ Carbon-ions } & 0.421 & $(0.322-0.520)$ & & & \\
\hline & 5-year disease-specific survival & & & & \\
\hline CRT & 0.435 & $(0.311-0.559)$ & 0.045 & 0.471 & 0.051 \\
\hline Carbon-ions & 0.643 & $(0.486-0.801)$ & & & \\
\hline
\end{tabular}

Abbreviations: CI, confidence interval; CRT, conventional radiotherapy; SBRT, stereotactic body radiotherapy.

* Pooled estimates are based on a study population with $82 \%$ medically inoperable patients.

** $p$-Value for the difference between the treatments.

studies. This may have underestimated the pooled estimates for CRT, since oncology care as well as disease staging for NSCLC has improved considerably in the last decade [62]. In the present analysis studies were included regardless of their follow-up period. This can be criticized, especially with regard to the 5-year outcomes. However, we feel that, although they are uncertain and should be handled carefully, the 5-year outcomes are of importance to the present study. We therefore decided to include all studies in the analyses that reported 5-year results, although we emphasize that the results of these analyses should be interpreted with caution.
Although meta-analyses of observational studies can be a solution when no RCTs are available, this method can only be used when sufficient observational data are available. We did not pool the occurrence of adverse events in a meta-regression due to the many studies with zero adverse events. Also, due to a lack of data we were unable to pool the effectiveness of proton and carbon-ion treatment for more advanced stages of NSCLC. Promising results for proton therapy in stage III disease were presented by Shioyama et al. [56], but these results were only based on 9 patients and are therefore excluded from the current analysis. Additionally, preli- 
Table 4

Occurrence of adverse events grade $3-5^{*}$ for each treatment modality in patients with stage I NSCLC.

\begin{tabular}{|c|c|c|c|c|c|c|c|c|c|c|}
\hline Treatment & $\begin{array}{l}N \\
\text { events }\end{array}$ & $\begin{array}{l}N \text { at } \\
\text { risk }\end{array}$ & Proportion & $\left(95 \% \mathrm{CI}^{* *}\right)$ & Source & $\begin{array}{l}N \\
\text { events }\end{array}$ & $\begin{array}{l}N \text { at } \\
\text { risk }\end{array}$ & Proportion & $\left(95 \% \mathrm{Cl}^{* *}\right)$ & Source \\
\hline & \multicolumn{5}{|c|}{ Pneumonitis grade $3 / 4$} & \multicolumn{5}{|c|}{ Oesophagitis grade $3 / 4$} \\
\hline CRT & 2 & 867 & 0.0023 & $\begin{array}{l}(0.0003- \\
0.0083)\end{array}$ & {$[30,32,33,35-37,40]$} & 1 & 831 & 0.0012 & $\begin{array}{l}(0.0000- \\
0.0067)\end{array}$ & $\begin{array}{l}{[30,32,33,35-} \\
37,40]\end{array}$ \\
\hline SBRT & 16 & 800 & 0.0200 & $\begin{array}{l}(0.0115- \\
0.0323)\end{array}$ & $\begin{array}{l}{[21,23,41-} \\
44,46,47,49]\end{array}$ & 2 & 840 & 0.0024 & $\begin{array}{l}(0.0003- \\
0.0086)\end{array}$ & $\begin{array}{l}{[21,23,41-44,46-} \\
49]\end{array}$ \\
\hline Protons & 1 & 126 & 0.0079 & $\begin{array}{l}(0.0002- \\
0.0434)\end{array}$ & {$[51-53]$} & 0 & 126 & 0.0000 & $(0.0290)$ & {$[51-53]$} \\
\hline \multirow[t]{2}{*}{$\begin{array}{l}\text { Carbon- } \\
\text { ions }\end{array}$} & 3 & 210 & 0.0143 & $\begin{array}{l}(0.0030- \\
0.0412)\end{array}$ & {$[55-57]$} & $\mathrm{nr}$ & $\mathrm{nr}$ & - & - & \\
\hline & \multicolumn{5}{|c|}{ Irreversible dyspnoea grade $3 / 4$} & \multicolumn{5}{|c|}{ Treatment-related death (grade 5) } \\
\hline CRT & 5 & 980 & 0.0051 & $\begin{array}{l}(0.0017- \\
0.0119)\end{array}$ & {$[30-33,35-37,40]$} & 1 & 980 & 0.0010 & $\begin{array}{l}(0.0000- \\
0.0057)\end{array}$ & {$[30-33,35-37,40]$} \\
\hline SBRT & 6 & 769 & 0.0078 & $\begin{array}{l}(0.0029- \\
0.0169)\end{array}$ & $\begin{array}{l}{[21,23,42-} \\
44,46,47,49]\end{array}$ & 6 & 870 & 0.0069 & $\begin{array}{l}(0.0025- \\
0.0150)\end{array}$ & $\begin{array}{l}{[21,23,41-44,46-} \\
49]\end{array}$ \\
\hline Protons & 0 & 58 & 0.0000 & $(0.0620)$ & {$[52,53]$} & 0 & 126 & 0.0000 & $(0.0290)$ & {$[51-53]$} \\
\hline $\begin{array}{l}\text { Carbon- } \\
\text { ions }\end{array}$ & 0 & 210 & 0.0000 & $(0.0170)$ & {$[55-57]$} & 0 & 210 & 0.0000 & $(0.0170)$ & [55-57] \\
\hline
\end{tabular}

Abbreviations: CRT, conventional radiotherapy; SBRT, stereotactic body radiotherapy; CI, confidence interval.

* Adverse events were graded in accordance with the CTCAE scoring system [19].

When the number of events was 0 , only the upper limit of the confidence interval was calculated.

minary results from conference presentations indicated that for stage III NSCLC proton therapy combined with chemotherapy results in less adverse events than IMRT and chemotherapy [6365]. Unfortunately it will take a number of years before survival results can be derived from this study. Nevertheless, these preliminary results emphasize the potential clinical benefit of particle therapy in advanced NSCLC, being a reduction of adverse events and higher survival due to a higher radiation dose to the tumor.

A number of literature reviews that separately addressed the effectiveness of CRT [66-69], SBRT [70] and particle therapy [15] were published recently. Although no actual meta-analysis of particle therapy in NSCLC has been published until now, there has been an attempt to calculate pooled estimates for the effectiveness of particle and photon therapy by Lodge et al. [2]. These estimates were on average lower than the pooled estimates presented in the current study. This difference can be explained by two main factors. First, Lodge et al. used a different method than our random effects meta-analysis and their estimates are unweighted. Second, the present review included more recent studies, and especially these newer studies tend to show better results.

Regarding potential effect modifiers, the present study found that the difference in the percentage of medically inoperable patients between the study populations significantly influenced the outcome. It was already shown in previous studies that operable patients who had refused surgery had better outcomes than medically inoperable patients $[24,25,46]$. The low percentage of medically inoperable patients in some particle studies may therefore overstate the effectiveness of particle therapy. In the present study we found that correcting for differences in the percentage of medically inoperable patients indeed resulted in lower pooled estimates for particle therapy. However, four studies did not report the percentage of medically inoperable patients in their study population. Although we tackled this using multiple imputation on our missing data, this emphasizes the importance that authors fully document the characteristics of the study populations in their papers. The difference in percentage of small $(<3 \mathrm{~cm})$ tumors between study populations was not found to influence the results of the meta-analysis. Although smaller stage I tumors are associated with higher expected survival [68], differences in the percentage of small tumors between the study populations were not modifying the results of the metaanalysis for stage I inoperable NSCLC.

Another possible source of bias is selection bias. SBRT and especially particle therapy are highly specialist treatments, only avail- able to a limited number of patients. By examining and correcting for influencing characteristics we have tried to eliminate selection bias as much as possible.

In the SBRT and particle studies, higher doses are given to the tumor, which is likely to, at least partly, explain the higher survival for these treatments as opposed to conventional radiotherapy. Hence, if it were possible to give such higher doses to the tumor using conventional radiotherapy, CRT would probably show better survival results.

In stage I NSCLC, especially for proton therapy, large uncertainty exists on the effectiveness of particle therapy. While the two most recent proton studies showed promising results, the older studies showed lower survival results. This may be the result of improved fractionation schedules or techniques. For carbon-ion therapy there is less variation and thus uncertainty, presumably because all studies are from the institution in Chiba, Japan. For a long time Chiba was the only carbon ion institute in the world, but carbonion facilities are currently under construction in Italy and Germany. However, it obviously takes a number of years before survival data from these institutes will be published.

The present study shows that although RCTs generate the highest level of evidence, observational studies can also be used to compare the effectiveness of different treatment modalities. It is however important that the observational studies are well documented and present similar endpoints.

From the results of this meta-analysis of observational studies it is clear that particle therapy results in higher survival rates than CRT in stage I inoperable NSCLC patients. However, the survival rates of particle therapy are equal to those of SBRT in these patients. Based on the currently available data, although preliminary results show a trend towards less adverse events with particle therapy than with photon therapy, no firm conclusions can be drawn on the reduction of side effects after particle therapy. Particle therapy may be more beneficial in stage III NSCLC, where 2-year survival is only $26-36 \%$ with concurrent chemoradiation with photons, and severe adverse events occur more frequently. However, more evidence is needed on whether particle therapy is actually beneficial in advanced stage NSCLC.

\section{Acknowledgement}

This study was funded by an unrestricted grant from Siemens Medical Solutions. 


\section{Appendix 1. Flow diagram of the search results for particle therapy (left) and photon therapy (right)}

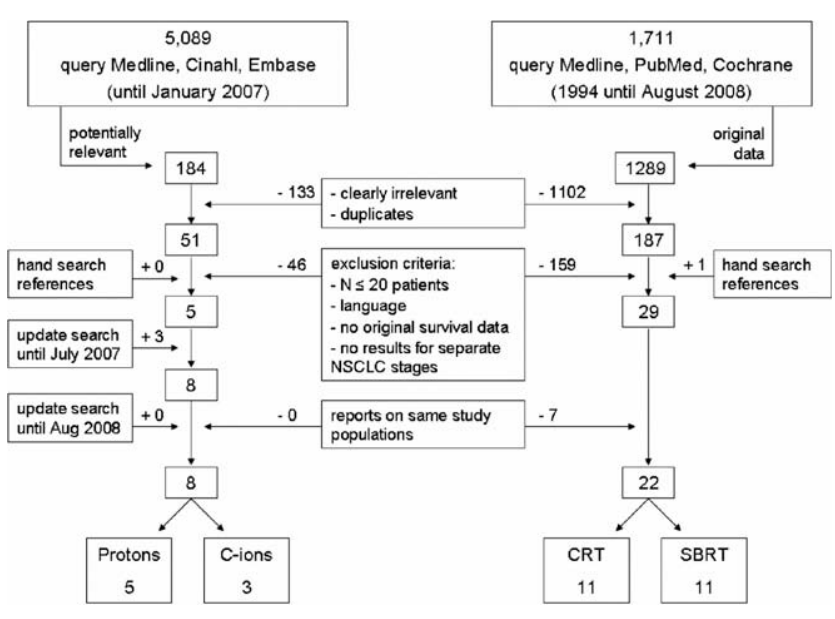

\section{References}

[1] Brada M, Pijls-Johannesma M, De Ruysscher D. Proton therapy in clinical practice: current clinical evidence. J Clin Oncol 2007;25:965-70.

[2] Lodge M, Pijls-Johannesma M, Stirk L, Munro AJ, De Ruysscher D, Jefferson T. A systematic literature review of the clinical and cost-effectiveness of hadron therapy in cancer. Radiother Oncol 2007;83:110-22.

[3] Olsen DR, Bruland OS, Frykholm G, Norderhaug IN. Proton therapy - a systematic review of clinical effectiveness. Radiother Oncol 2007;83:123-32.

[4] Pijls-Johannesma M, Grutters JP, Lambin P, Ruysscher DD. Particle therapy in lung cancer: where do we stand? Cancer Treat Rev 2008;34:259-67.

[5] Widesott L, Amichetti M, Schwarz M. Proton therapy in lung cancer: clinical outcomes and technical issues. A systematic review. Radiother Oncol 2008;86:154-64.

[6] Bentzen SM. Randomized controlled trials in health technology assessment: overkill or overdue? Radiother Oncol 2008;86:142-7.

[7] Glatstein E, Glick J, Kaiser L, Hahn SM. Should randomized clinical trials be required for proton radiotherapy? An alternative view. J Clin Oncol 2008;26:2438-9.

[8] Glimelius B, Montelius A. Proton beam therapy - do we need the randomised trials and can we do them? Radiother Oncol 2007;83:105-9.

[9] Goitein M, Cox JD. Should randomized clinical trials be required for proton radiotherapy? J Clin Oncol 2008;26:175-6.

[10] Tepper JE. Protons and parachutes. J Clin Oncol 2008;26:2436-7.

[11] Anonymous. Introducing new treatments and technologies into the clinic. J Clin Oncol 2008;26:2425.

[12] Suit H, Kooy H, Trofimov A, et al. Should positive phase III clinical trial data be required before proton beam therapy is more widely adopted? No. Radiother Oncol 2008;86:148-53.

[13] Morgan, JP. A patient's perspective on randomized clinical trials for proton radiotherapy. J Clin Oncol 2008;26:2592.

[14] Haasbeek CJ, Senan S, Smit EF, Paul MA, Slotman BJ, Lagerwaard FJ. Critical review of nonsurgical treatment options for stage I non-small cell lung cancer. Oncologist 2008;13:309-19.

[15] Stroup DF, Berlin JA, Morton SC, et al. Meta-analysis of observational studies in epidemiology: a proposal for reporting. Meta-analysis Of Observational Studies in Epidemiology (MOOSE) group. JAMA 2000;283:2008-12.

[16] Auperin A, Rolland E, Curran WJ, et al. Concomitant radio-chemotherapy (RT$\mathrm{CT}$ ) versus sequential RT-CT in locally advanced non-small cell lung cancer (NSCLC): a meta-analysis using individual patient data (IPD) from randomised clinical trials (RCTs). J Thorac Oncol 2007;2:S310.

[17] Rowell NP, O'Rourke NP. Concurrent chemoradiotherapy in non-small cell lung cancer. Cochrane Database Syst Rev 2004;4:CD002140.

[18] Bentzen SM, Saunders MI, Dische S. From CHART to CHARTWEL in non-small cell lung cancer: clinical radiobiological modelling of the expected change in outcome. Clin Oncol [R Coll Radiol] 2002;14:372-81.

[19] National Cancer Institute. Common Terminology Criteria for Adverse Events version 3.0 (CTCAE). Available at: http://ctep.cancer.gov/forms/ CTCAEv3.pdf.2006.

[20] DerSimonian R, Laird N. Meta-analysis in clinical trials. Control Clin Trials 1986;7:177-88

[21] Rubin DB, Schenker N. Multiple imputation in health-care databases: an overview and some applications. Stat Med 1991;10:585-98.

[22] van Buuren S, Boshuizen HC, Knook DL. Multiple imputation of missing blood pressure covariates in survival analysis. Stat Med 1999;18:681-94.
[23] Hoyer M, Roed H, Hansen AT, et al. Prospective study on stereotactic radiotherapy of limited-stage non-small-cell lung cancer. Int J Radiat Oncol Biol Phys 2006;66:S128-35.

[24] Onishi H, Araki T, Shirato H, et al. Stereotactic hypofractionated high-dose irradiation for stage I nonsmall cell lung carcinoma: clinical outcomes in 245 subjects in a Japanese multiinstitutional study. Cancer 2004;101:1623-31.

[25] Onishi H, Shirato H, Nagata Y, et al. Hypofractionated stereotactic radiotherapy (HypoFXSRT) for stage I non-small cell lung cancer: updated results of 257 patients in a Japanese multi-institutional study. J Thorac Oncol 2007;2:S94-100.

[26] Fukumoto S, Shirato H, Shimzu S, et al. Small-volume image-guided radiotherapy using hypofractionated, coplanar, and noncoplanar multiple fields for patients with inoperable Stage I nonsmall cell lung carcinomas. Cancer 2002;95:1546-53.

[27] Hiraoka M, Matsuo Y, Nagata Y. Stereotactic body radiation therapy (SBRT) for early-stage lung cancer. Cancer Radiother 2007;11:32-5.

[28] Nagata Y, Takayama K, Matsuo Y, et al. Clinical outcomes of a phase I/II study of $48 \mathrm{~Gy}$ of stereotactic body radiotherapy in 4 fractions for primary lung cancer using a stereotactic body frame. Int J Radiat Oncol Biol Phys 2005;63:1427-31.

[29] Onimaru R, Fujino M, Yamazaki K, et al. Steep dose-response relationship for stage I non-small-cell lung cancer using hypofractionated high-dose irradiation by real-time tumor-tracking radiotherapy. Int J Radiat Oncol Biol Phys 2008;70:374-81.

[30] Onishi H, Kuriyama K, Komiyama T, et al. Clinical outcomes of stereotactic radiotherapy for stage I non-small cell lung cancer using a novel irradiation technique: patient self-controlled breath-hold and beam switching using a combination of linear accelerator and CT scanner. Lung Cancer 2004;45:45-55.

[31] Baumann P, Nyman J, Lax I, et al. Factors important for efficacy of stereotactic body radiotherapy of medically inoperable stage I lung cancer. A retrospective analysis of patients treated in the Nordic countries. Acta Oncol 2006;45:787-95.

[32] Gauden S, Ramsay J, Tripcony L. The curative treatment by radiotherapy alone of stage I non-small cell carcinoma of the lung. Chest 1995;108:1278-82.

[33] Lagerwaard FJ, Senan S, van Meerbeeck JP, Graveland WJ. Has 3-D conformal radiotherapy (3D CRT) improved the local tumour control for stage I non-small cell lung cancer? Radiother Oncol 2002;63:151-7.

[34] Morita K, Fuwa N, Suzuki Y, et al. Radical radiotherapy for medically inoperable non-small cell lung cancer in clinical stage I: a retrospective analysis of 149 patients. Radiother Oncol 1997;42:31-6.

[35] Sibley GS, Jamieson TA, Marks LB, Anscher MS, Prosnitz LR. Radiotherapy alone for medically inoperable stage I non-small-cell lung cancer: the Duke experience. Int J Radiat Oncol Biol Phys 1998;40:149-54.

[36] Firat S, Bousamra M, Gore E, Byhardt RW. Comorbidity and KPS are independent prognostic factors in stage I non-small-cell lung cancer. Int J Radiat Oncol Biol Phys 2002;52:1047-57.

[37] Hayakawa K, Mitsuhashi N, Saito Y, et al. Limited field irradiation for medically inoperable patients with peripheral stage I non-small cell lung cancer. Lung Cancer 1999;26:137-42.

[38] Krol AD, Aussems P, Noordijk EM, Hermans J, Leer JW. Local irradiation alone for peripheral stage I lung cancer: could we omit the elective regional nodal irradiation? Int J Radiat Oncol Biol Phys 1996;34:297-302.

[39] Bradley JD, Wahab S, Lockett MA, Perez CA, Purdy JA. Elective nodal failures are uncommon in medically inoperable patients with Stage I non-small-cell lung carcinoma treated with limited radiotherapy fields. Int J Radiat Oncol Biol Phys 2003;56:342-7.

[40] Din OS, Lester J, Cameron A, et al. Routine use of continuous, hyperfractionated, accelerated radiotherapy for non-small-cell lung cancer: a five-center experience. Int J Radiat Oncol Biol Phys 2008;72:716-22.

[41] Fang LC, Komaki R, Allen P, Guerrero T, Mohan R, Cox JD. Comparison of outcomes for patients with medically inoperable Stage I non-small-cell lung cancer treated with two-dimensional vs. three-dimensional radiotherapy. Int J Radiat Oncol Biol Phys 2006;66:108-16.

[42] Jeremic B, Shibamoto Y, Acimovic L, Milisavljevic S. Hyperfractionated radiotherapy alone for clinical stage I nonsmall cell lung cancer. Int J Radiat Oncol Biol Phys 1997;38:521-5.

[43] Koto M, Takai Y, Ogawa Y, et al. A phase II study on stereotactic body radiotherapy for stage I non-small cell lung cancer. Radiother Oncol 2007;85:429-34

[44] Lagerwaard FJ, Haasbeek CJ, Smit EF, Slotman BJ, Senan S. Outcomes of riskadapted fractionated stereotactic radiotherapy for stage I non-small-cell lung cancer. Int J Radiat Oncol Biol Phys 2008;70:685-92.

[45] Nyman J, Johansson KA, Hulten U. Stereotactic hypofractionated radiotherapy for stage I non-small cell lung cancer - mature results for medically inoperable patients. Lung Cancer 2006;51:97-103.

[46] Uematsu M, Shioda A, Suda A, et al. Computed tomography-guided frameless stereotactic radiotherapy for stage I non-small cell lung cancer: a 5-year experience. Int J Radiat Oncol Biol Phys 2001;51:666-70.

[47] Xia T, Li H, Sun Q, et al. Promising clinical outcome of stereotactic body radiation therapy for patients with inoperable Stage I/II non-small-cell lung cancer. Int J Radiat Oncol Biol Phys 2006;66:117-25.

[48] Zimmermann FB, Geinitz H, Schill S. Et al. Stereotactic hypofractionated radiotherapy in stage I (T1-2 NO M0) non-small-cell lung cancer (NSCLC). Acta Oncol 2006;45:796-801.

[49] Scorsetti M, Navarria P, Facoetti A, et al. Effectiveness of stereotactic body radiotherapy in the treatment of inoperable early-stage lung cancer. Anticancer Res 2007;27:3615-9. 
[50] Timmerman R, McGarry R, Yiannoutsos C, et al. Excessive toxicity when treating central tumors in a phase II study of stereotactic body radiation therapy for medically inoperable early-stage lung cancer. J Clin Oncol 2006;24:4833-9.

[51] Salazar OM, Sandhu TS, Lattin PB, et al. Once-weekly, high-dose stereotactic body radiotherapy for lung cancer: 6-year analysis of 60 early-stage, 42 locally advanced, and 7 metastatic lung cancers. Int J Radiat Oncol Biol Phys 2008;72:707-15.

[52] Bush DA, Slater JD, Bonnet R, et al. Proton-beam radiotherapy for early-stage lung cancer. Chest 1999;116:1313-9.

[53] Bush DA, Slater JD, Shin BB, Cheek G, Miller DW, Slater JM. Hypofractionated proton beam radiotherapy for stage I lung cancer. Chest 2004:126:1198-203.

[54] Hata M, Tokuuye K, Kagei K, et al. Hypofractionated high-dose proton beam therapy for stage I non-small-cell lung cancer: preliminary results of a phase I/ II clinical study. Int J Radiat Oncol Biol Phys 2007;68:786-93.

[55] Nihei K, Ogino T, Ishikura S, Nishimura H. High-dose proton beam therapy for Stage I non-small-cell lung cancer. Int J Radiat Oncol Biol Phys 2006;65:107-11.

[56] Shioyama Y, Tokuuye K, Okumura $T$, et al. Clinical evaluation of proton radiotherapy for non-small-cell lung cancer. Int J Radiat Oncol Biol Phys 2003;56:7-13.

[57] Miyamoto T, Baba M, Sugane T, et al. Carbon ion radiotherapy for stage I nonsmall cell lung cancer using a regimen of four fractions during 1 week. J Thorac Oncol 2007;2:916-26.

[58] Miyamoto T, Baba M, Yamamoto N, et al. Curative treatment of Stage I nonsmall-cell lung cancer with carbon ion beams using a hypofractionated regimen. Int J Radiat Oncol Biol Phys 2007;67:750-8.

[59] Miyamoto T, Yamamoto N, Nishimura H, et al. Carbon ion radiotherapy for stage I non-small cell lung cancer. Radiother Oncol 2003;66:127-40.

[60] Sweeting MJ, Sutton AJ, Lambert PC. What to add to nothing? Use and avoidance of continuity corrections in meta-analysis of sparse data. Stat Med 2004;23:1351-75.
[61] Blettner M, Sauerbrei W, Schlehofer B, Scheuchenpflug T, Friedenreich C. Traditional reviews, meta-analyses and pooled analyses in epidemiology. Int J Epidemiol 1999;28:1-9.

[62] Hoyer M. Improved accuracy and outcome in radiotherapy of lung cancer Radiother Oncol 2008;87:1-2.

[63] Cox JD, Chang J, Liao Z, et al. Acute esophageal reactions from proton beam therapy, concurrent chemotherapy for non-small cell lung cancer (NSCLC): reduction in incidence, severity despite higher doses. J Thorac Oncol 2007;2:S449.

[64] Komaki R, Sejpal SV, Wei X, et al. Reduction of bone marrow suppression for patients with stage III NSCLC treated by proton and chemotherapy compared with IMRT and chemotherapy. Conference of the Particle Therapy Co-operative Group, vol. 47. Jacksonville, Florida; 2008. p. 14.

[65] Sejpal SV, Komaki R, Wei X, et al. Does proton beam radiotherapy (PBT) reduce treatment related pneumonitis (TRP) compared to intensity modulated related radiation therapy (IMRT) in patients with locally advanced non-small cell lung cancer (NSCLC) treated with concurrent chemotherapy? Conference of the Particle Therapy Co-operative Group, vol. 47. Jacksonville, Florida; 2008. p. 22.

[66] Jeremic B, Classen J, Bamberg M. Radiotherapy alone in technically operable, medically inoperable, early-stage (I/II) non-small-cell lung cancer. Int J Radiat Oncol Biol Phys 2002;54:119-30.

[67] Qiao X, Tullgren O, Lax I, Sirzen F, Lewensohn R. The role of radiotherapy in treatment of stage I non-small cell lung cancer. Lung Cancer 2003;41:1-11.

[68] Rowell NP, Williams CJ. Radical radiotherapy for stage I/II non-small cell lung cancer in patients not sufficiently fit for or declining surgery (medically inoperable): a systematic review. Thorax 2001;56:628-38.

[69] Zimmermann FB, Bamberg M, Molls M, Jeremic B. Radiation therapy alone in early stage non-small cell lung cancer. Semin Surg Oncol 2003;21:91-7.

[70] Nguyen NP, Garland L, Welsh J, Hamilton R, Cohen D, Vincent VH. Can stereotactic fractionated radiation therapy become the standard of care for early stage non-small cell lung carcinoma. Cancer Treat Rev 2008;34:719-27. 